\title{
The Relevance of Financial Integration Across Europe: A Dynamic Panel Data Approach
}

\author{
Onur Özdemir ${ }^{1, *}$ and Fatih Kayhan ${ }^{2}$ \\ ${ }^{I}$ Asst. Prof. Dr., Istanbul Gelisim University, Faculty of Economics, Administrative and Social Sciences, \\ Department of International Trade and Finance (English). \\ ${ }^{2}$ Asst. Prof. Dr., Kırklareli University, Faculty of Applied Sciences, Department of Banking and Finance.
}

\begin{abstract}
This paper aims to examine the degree of financial integration for selected European countries from 1980 to 2019 using dynamic panel data approaches, covering the panel unit-root tests, cointegration analysis, panel Granger causality tests, and the DOLS and FMOLS methods. Saving and investment rates are found to be stationary at order of integration one, i.e., I (1). It is also found to be that the series are cointegrated along with different methods. Similar to that of cointegration analysis, it is observed that the causality between the variables is statistically significant and bidirectional. Finally, the current study proceeds to test the direction of coefficients for the estimation of the long-run relationship among the series by way of using panel DOLS and FMOLS methods. The values of coefficients show that the effects of each variable on another are both positive and statistically significant at the $1 \%$ level. Therefore, the empirical findings point out that strong financial integration is relevant to those European countries.
\end{abstract}

Keywords: Financial Integration, International Capital Mobility, Feldstein-Horioka Puzzle, Dynamic Panel Data Approach, European Economy.

JEL Classification: C33, F32, F36

\section{INTRODUCTION}

One of the major topics in macroeconomics can be considered as the relevance of financial market integration across different countries and regions. In particular, the degree of capital mobility that has been risen over the last four decades has played a crucial role in the policymaking process. While this is not specific to any kind of country groups, most of the transfers of capital were done by the high-income economies where the financial relations were well-designed to a large extent. Some of the mechanism that could lead those countries to interact with each other financially can be ranged as follows: (i) the development of information and telecommunication technologies, (ii) easy access to the knowledgebased products, (iii) the rising level of automatization and robotization in knowledge production, and (iv) increasing degree of integration in financial markets. In line with the final factor (i.e., the increasing degree of integration in financial markets), two types of approaches are heavily criticized for their assumptions in consideration of the financial integration process. On the one hand, the pro-active arguments in parallel to the development of financial markets across different economies support that more integrated financial systems stimulate a higher level of economic growth

\footnotetext{
*Address correspondence to this author at Asst. Prof. Dr., Istanbul Gelisim University, Faculty of Economics, Administrative and Social Sciences, Department of International Trade and Finance (English),

E-mail: onozdemir@gelisim.edu.tr;
}

by leading an efficient allocation of resources. However, the other group of arguments notes that more integrated financial markets could spread out the cross-border finance-led shocks in one economy to others; and therefore, it could increase the risk level of possibility for the financial contagion (Beine et al., 2010; Hassan et al., 2014). Therefore, the current literature on the relevance of financial integration and its impact on economic performance is still far away from being resolved. In the context of this uncompromised context for the degree of capital mobility, this paper deals with the degree of financial integration for selected 27 European countries by revisiting one of the most discusses macroeconomic paradox called as the Feldstein-Horioka puzzle. In essence, Feldstein and Horioka (1980) measure the degree of financial integration practicing upon the correlation of domestic saving with investment rates. The major concern of their study is to question whether domestic saving is sensitive to the changes in investment rates towards an increasing degree of financial integration across industrialized countries. Their empirical results present a high correlation among two indicators during 1960-1974. Even though the results show that the correlation is unambiguously high for most of the countries, the capital is prone to be mobile across borders. In other words, the results should be assumed as contradictory since capital mobility appears to be increasing ever since the beginning of 1960s (Alexakis and Apergis, 1994; Beitone et al., 2006). Therefore, these paradoxical findings lead their methodology to be known as Feldstein-Horioka (hereafter F-H) puzzle in the literature (Obstfeld and Rogoff, 2000). In that sense, 
Guillaumin (2009: 314) argues that the F-H puzzle is subjected to two critiques related with the econometric and statistical caveats which are mostly related with a bias towards a significant, positive, and close to one coefficient and the economic and historical facts that represent the difference between an expected coefficient close to zero and its effective value.

The distinguishing feature of the F-H puzzle is that excess saving is free to move from the host country to the others where the investment is aimed to be realized in parallel to unrestricted mobility of capital among each other. It indirectly means that the domestic investment is irrespective of domestic saving but also correlates with foreign saving. However, this leads most of the researchers to criticize a given empirical finding in which case the stylized facts are contradicted with the expectations. In other words, a bulk of studies show that the correlation between domestic saving and domestic investment is still prevailing for most of the countries although they have nothing to limit capital mobility. This challenge for the F-H approach has been investigated through a large number of possible reasons such as sample selection and size problem, simultaneity bias, financial shocks, misspecification errors, omitted variable bias, and/or nonlinearity problems. Therefore, the current literature is not closed to find a common consensus for the reason why domestic investment is a function of domestic saving than foreign saving. According to Bibi and Jalil (2016: 234), this domestic level correlation for saving and investment can thus be called home bias instead of mobility. Although this paper entitles some of the assumptions developed by Feldstein and Horioka (1980) and Feldstein (1983) to show that the home bias effects for the allocation of domestic saving are only significant under specific circumstances, the time-specific saving-retention coefficient can be differed along with a change in capital movements. In consideration of that theoretical background, Figure 1 represents the savinginvestment nexus for the selected 27 European countries over the 1980-2019 period, which implies that the strong correlation among the two indicators is prevailing.

Starting from the very beginning of discussions on the F-H puzzle, a bulk of studies have attempted to measure the degree of financial integration using several empirical procedures. Even though the results are mixed across different samples, they have produced substantial arguments to explain the reasons that may lead to the emergence of this paradox. On the one hand, many of those studies have been found that the F-H puzzle is still binding for many countries (Sinn, 1992; Watson, 2001; Gunji, 2003; Schmidt, 2016). However, the other strand of literature has been specified that the stylized facts reflect many different outcomes than what the traditional perspectives argue (Obstfeld, 1986; De Vita and Abbott, 2002; Katsimi and Zoega, 2016). This contradictory structure indicates that the literature on the F-H puzzle shows no sign of abating. First, a large part of the literature has been tried to statistically prove that domestic saving and investment are highly correlated under perfect capital mobility. For instance, Feldstein and Bachetta (1991) validate the domestic level correlation between saving and investment for 23 OECD countries but also confirm that the saving-retention coefficient has a downward trend throughout time, which results from the removal of restrictions on financial flows, newly introduced hedging markets, and the modernization of the institutional structure of the financial sector. Besides, Coakley and Kulasi (1997), Jansen (1998), and Shibata and Shintani (1998) focus on intertemporal budget constraints to show that this is the major reason why domestic saving is highly correlated with domestic investment in the presence of free capital mobility and strongly integrated financial sector. The economic meaning of these findings depends on the theoretical context that if there is an excess level of investment than the domestic saving, the difference should be funded by way of foreign capital transfers, which cause to emerge a specific amount of current account deficit. The unique feature for the maintenance of deficit in current account depends on the fact that the capital is highly mobile across boundaries and thus the domestic saving and investment levels should not be equal.

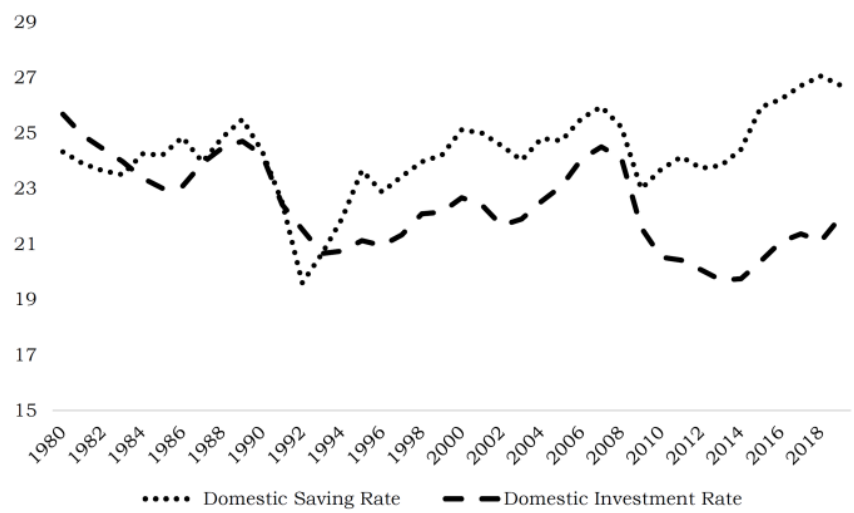

Fig. (1). The saving-investment trend over time.

Source: World Development Indicators; Author's own calculations.

However, Sachs (1981), Ghosh (1995), and Coakley and Kulasi (1997) argue that the ongoing positive correlation among the two indicators is particularly linked to the current account volatility than the free movement of capital, which is promoted by public and monetary policy agenda (Summers, 1988; Narayan, 2005a). According to Tesar (1991), the given correlation can also be explained by way of looking at the economic indicators of countries where the advanced economies have a relatively high level of domestic saving and investment than the low-income economies and thus they are more prone to use local financial resources, irrespective of the degree of financial integration. In that vein, the lowincome economies are much strongly dependent on capital mobility to realize investment-saving equality, which results in having much lower saving-retention coefficients compared to high-income economies (Murphy, 1984; Tesar, 1991). While these are some of the reasons that may support the theoretical background of the result predicted by Feldstein and Horioka (1980), there are also other reasons that may influence the given structure of the empirical findings, which can be ranged as follows: identification problem (Coakley et al., 1998), the omitted variable bias (Baxter and Crucini, 1993), the determinants of economic growth (Hamada and Iwata, 1989), a failure to realize financial market integration (Cardia, 1992), the difference of transaction cost between internal and external investment (Niehans, 1992), legal restrictions and tax impediments (Devereux, 1996), the differences in exchange rate regimes (Edwards, 2004), endogeneity problem (Kasuga, 2004), time incon- 
sistency (Baxter and Crucini, 1993), the sensitivity of saving and investment to economic regimes (Ho, 2002), sample sensitivity (Cadoret, 2001), nonlinearity in current account dynamics (Chortareas et al., 2004), and the differences in policy regimes (Sarno and Taylor, 1998).

Moreover, the other part of the literature confirms the positive correlation between domestic saving and investment by rejecting the low capital mobility assumption. The change in exogenous variables provides a high correlation between domestic saving and investment, even under perfect capital mobility (Sinn, 1992; Taslim, 1995). For instance, Taslim (1995) remarks that the dynamic relationship between domestic saving and investment is determined through economic growth and systemic intervention by government policies. In consideration of the reasons behind the savinginvestment nexus, Murphy (1984) and Sinn (1992) note that a high correlation between two indicators is dependent on the country size such as the advanced economies where the foreign funds are less needed for more investment. The country size may have an ample effect on the interest rate (Sinn, 1992) and thus the countries having well-developed economic structure may be less dependent on foreign funds (Harberger, 1990). On the one hand, the countries with a high level of domestic saving indirectly means that they have more potential to affect the interest rate, which results in the decline of a world interest rate and thereby causes the level of investment increase in the host country. On the other hand, the investors are more prone to use domestic financial sources if the country is large enough to fund its investment. By doing this, they get rid of the potential costs occurring in transactions for goods and services; and therefore, they are less likely to engage with financial funds or borrowings. According to Payne and Kumazawa (2006), the savingretention coefficient is relatively much higher in developed countries compared to developing countries. Some of the major reasons why this difference in country groups is relevant over time can be ranged as follows: (i) the presence of foreign aid (Isaksson, 2001), (ii) the differences in financial market conditions (Kasuga, 2004), and (iii) the differences in openness degree of countries (Wong, 1990). Vamvakidis and Wacziarg (1998) also note that the conventional assumptions on the F-H puzzle can be turned into negative when the developing country groups are explicitly integrated into the sample of other countries in the presence of the abovementioned factors and the others. For instance, the heterogeneous financial motives and variance in factor endowments among different countries may lead to an occurrence of international diversification. In addition, developing countries may have various channels to attract foreign investors to invest in those countries by diversifying financial risks with several instruments. This case also considers the uncertainty level and risk-return levels of financial assets. Furthermore, the developing countries may have an ample effect on the saving-investment nexus due to the reason that they vary on access to foreign capital, irrespective of the degree of capital mobility. In case of empirical procedures, Bibi and Jalil (2016) classify those techniques into three categories to estimate the statistical validity of the F-H puzzle. The first set of studies use cross-sectional-data and Ordinary Least Squares (OLS) estimators to show that the degree of capital mobility is low in international transactions and thus the sav- ing-retention coefficient is high enough to confirm the validity of the F-H puzzle (Feldstein, 1983; Murphy, 1984; Sinn, 1992). The second set of studies also use those techniques but indicates that there is either having low or no correlation between saving and investment that pointing out a lack of international capital mobility (Bayoumi et al., 1999; Obstfeld and Rogoff, 2000). These controversial findings led many researchers to deal with different procedures such as error correction methods and autoregressive distributed lags approaches. Many of them show that the statistical significance between domestic saving and investment is prevailing and thereby reflect a long-run linkage by validating the arguments of Feldstein and Horioka (1980) in which the degree of international capital mobility is low (Jansen, 1996; Narayan, 2005a, 2005b; Caporale et al., 2005). However, some other discussions developed by Barros and Gil-Alana (2015) and Ma and Li (2016) support the fact that those empirical findings do not support the long-run estimates of saving-investment nexus that implies the presence of a high degree of financial integration, where the saving-retention coefficient is low enough. Finally, the last strand of studies uses the panel data approach for several reasons such as providing of more accurate inference of model parameters, having a great capacity for capturing the complexity of the sample, having more control for the impact of omitted variables, having power to uncover dynamic linkages, generating more accurate predictions for individual outcomes through the pooling of data, and simplifying power of the statistical inferences (de Wet and van Eyden, 2005; Guillaumin, 2009; Bangake and Eggoh, 2011; Mosikari et al., 2017).

All in all, the goal of this paper is to examine the degree of financial integration in selected 27 European countries from 1980 to 2019 using recently developed panel data approaches such as unit-root techniques, cointegration analysis, Granger causality tests, and the DOLS and FMOLS procedures to detect long-run coefficients. First, we employ firstgeneration panel unit root tests along the lines of Maddala and $\mathrm{Wu}$ (1999), Hadri (2000), Levin et al. (2002), and Im et al. (2003), and second-generation panel unit root test along the lines of Pesaran (2007). Second, we also test for the presence of a long-run linkage between investment and saving rates using the following two cointegration testing procedures: Kao (1999) and Pedroni (1999, 2004). Third, we employ the panel Granger causality test developed by Dumitrescu and Hurlin (2012) to investigate whether there is oneway or two-way relationship among the variables. Finally, we use panel Dynamic OLS (DOLS) and panel Fully Modified OLS (FMOLS) methods to determine the long-run coefficients along with their directions.

The paper is structured as follows: Section 2 provides an overview of the theoretical structure of the Feldstein-Horioka puzzle. Section 3 describes the data and the sources of the data. Section 4 summarizes the details of methodological approaches. Section 5 presents and discusses the empirical findings. Section 6 offers concluding remarks.

\section{THEORETICAL STRUCTURE OF FELDSTEIN- HORIOKA PUZZLE}

Before getting into the theoretical details of the F-H puzzle, the main rationale of its inner dynamics can briefly be sum- 
marized. In particular, it is aimed to measure the degree of financial integration and thereby the international capital mobility across advanced economies in terms of domestic saving-investment nexus. In other words, in their pioneering study, Feldstein and Horioka (1980) investigated the crosssectional correlation among these two indicators. According to their model, the domestic investment would be much dependent on foreign savings in parallel to an increasing degree of integration in financial markets across sample countries. Therefore, the domestic savings and investment will diverge from each other in terms of their correlation when the degree of capital mobility reaches its maximum. The significance of this correlation is measured by the saving-retention coefficient in the F-H approach, which is denoted by $\beta$. On the one hand, $\beta$ is supposed to be low (or close to zero) when the degree of capital mobility is high, implying that the statistical significance of the correlation between domestic saving and investment is not approved. On the other hand, $\beta$ is supposed to be high (or close to one) when the degree of capital mobility is restricted, implying that the correlation between domestic saving and investment is significant. In consideration of this framework, the cross-sectional correlation between saving and investment is examined by testing the following equation:

$$
\left(\frac{l}{Y}\right)_{i t}=\alpha+\beta\left(\frac{S}{Y}\right)_{i t}+\varepsilon_{i, t}
$$

where I/Y represents the ratio of investment over Gross Domestic Product (GDP), i.e., the investment rate. S/Y represents the ratio of saving over GDP, i.e., the saving rate. Indexes $i$ and $t$ stand for the selected country and year, respectively. $\alpha$ is the intercept, $\beta$ is the saving-retention coefficient, which indicates the effects of the rate of changes in investment on the saving rate (i.e., the degree of financial integration: in case of weak financial integration, $\beta$ is equal to 1 and in case of strong financial integration, $\beta$ is equal to 0 ), and $\varepsilon i, t$ represents the error term. This term is a random walk, with zero mean $(\mathrm{E}(\varepsilon)=0)$ and variance $\sigma 2$. By using the saving-retention coefficient, we can describe three types of possibilities about the economic structure. First, if this coefficient is close to zero, the domestic investment will be funded by foreign savings, where the degree of capital mobility is high. Second, if this coefficient is close to one, the domestic investment will be funded by domestic saving, where the degree of financial integration is low, and capital mobility is restricted. Finally, if this coefficient ranges between zero and one, this will be meant that the degree of capital mobility will be varied over time and thus it will be changed across countries along with the change in exogenous variables. The second case implies the F-H puzzle where the empirical findings show that the saving-retention coefficient is very close to one for 16 OECD countries during 1960-1974, implying that the degree of capital mobility and thereby the financial integration are quite low despite a large volume of international capital movements (Beitone et al., 2006). Therefore, this contradiction between a low degree of financial integration and a large volume of international capital movements are expressed as the F-H puzzle. The next section will describe the data using in the empirical procedures.

\section{DATA DESCRIPTION}

In this paper, the empirical validity of the F-H puzzle is investigated by the employment of the dataset derived from the World Bank, World Development Indicators (WDI) database. In essence, considering the basis of empirical structure developed by Feldstein and Horioka (1980), we will use only two types of variables to measure the saving-retention coefficient: (i) domestic saving ratio (\% of GDP) and (ii) domestic investment ratio (\% of GDP). First, we consider the estimation of the domestic investment ratio over GDP. However, this is not a smooth issue in terms of the selection process for the data because of the reason that it should be chosen in case of its robustness to estimate the change in domestic investment ratio (\% of GDP). In consideration of this knowledge, the current literature is theoretically separated into two fields. On the one hand, a mainstream approach uses the gross fixed capital formation to measure domestic investment. However, it causes some empirical problems since it neglects the presence of possible division across different sectors. In other words, it gathers all sectors to measure the behavior of investment. However, it may lead to some serious problems for the countries where the role of private sector is likely to have no market power on the determination of total investment and thereby leads to inaccurate estimates for the effects of domestic saving on domestic investment. On the other hand, there are also some studies, which decompose the total investment for different sectors. However, this method is also led to the emergence of issues towards making an aggregate analysis for the F-H puzzle. Therefore, we employ the first type of variable to measure domestic investment, which represents the gross fixed capital formation over GDP. To provide a statistical unity in terms of estimating the saving-retention coefficient, we employ domestic saving over GDP as the difference between GDP and final consumption expenditure. Moreover, both domestic saving and investment are measured on gross terms to provide a balance for data measurement. Table 1 shows the average values of investment and saving rates in selected 27 European countries. Table 2 summarizes the details, sources, and abbreviations of these variables. Finally, Table 3 presents descriptive statistics. In the next section, the empirical methods will be explained in detail.

Table 1. The Averages of Saving and Investment Rates, 19802019.

\begin{tabular}{|c|c|c|c|}
\hline Country & $\begin{array}{c}\text { Country } \\
\text { Code }\end{array}$ & $\begin{array}{c}\text { Average } \\
\text { Saving Rate }\end{array}$ & $\begin{array}{c}\text { Average } \\
\text { Investment Rate }\end{array}$ \\
\hline Albania & ALB & 7,827 & 28,43 \\
\hline Austria & AUT & 26,22 & 24,26 \\
\hline Belgium & BEL & 24,56 & 21,89 \\
\hline Bulgaria & BGR & 21,93 & 21,32 \\
\hline Cyprus & CYP & 20,28 & 22,81 \\
\hline Denmark & DNK & 25,71 & 20,31 \\
\hline Finland & FIN & 26,97 & 23,79 \\
\hline
\end{tabular}




\begin{tabular}{|c|c|c|c|}
\hline France & FRA & 22,34 & 21,94 \\
\hline Germany & DEU & 24,43 & 21,97 \\
\hline Greece & GRC & 15,08 & 21,01 \\
\hline Hungary & HUN & 23,51 & 22,79 \\
\hline Iceland & ISL & 22,62 & 22,30 \\
\hline Ireland & IRL & 32,77 & 22,95 \\
\hline Italy & ITA & 21,65 & 20,54 \\
\hline Luxembourg & LUX & 43,33 & 20,56 \\
\hline Malta & MLT & 21,12 & 21,49 \\
\hline Netherlands & NLD & 28,40 & 21,17 \\
\hline Norway & NOR & 33,91 & 23,76 \\
\hline Poland & POL & 20,79 & 19,14 \\
\hline Portugal & PRT & 17,54 & 23,50 \\
\hline Russia & RUS & 30,84 & 23,28 \\
\hline Spain & ESP & 22,35 & 22,88 \\
\hline Sweden & SWE & 26,82 & 23,46 \\
\hline Switzerland & CHE & 31,91 & 25,86 \\
\hline Turkey & TUR & 24,62 & 23,43 \\
\hline Ukraine & UKR & 22,80 & 19,84 \\
\hline United Kingdom & GBR & 15,01 & 18,75 \\
\hline
\end{tabular}

Table 2. Data Descriptions

\begin{tabular}{|c|c|c|c|}
\hline Variable & Abbreviations & Description & Source \\
\hline $\begin{array}{c}\text { Domestic } \\
\text { Saving } \\
\text { Rate }\end{array}$ & sav & $\begin{array}{c}\text { Gross Domes- } \\
\text { tic Saving } \\
\text { (\% of GDP) }\end{array}$ & $\begin{array}{c}\text { World Develop- } \\
\text { ment Indicators } \\
\text { (World Bank) }\end{array}$ \\
\hline $\begin{array}{c}\text { Domestic } \\
\text { Investment } \\
\text { Rate }\end{array}$ & inv & $\begin{array}{c}\text { Gross Fixed } \\
\text { Capital For- } \\
\text { mation } \\
(\% \text { of GDP) }\end{array}$ & $\begin{array}{c}\text { World Develop- } \\
\text { ment Indicators } \\
\text { (World Bank) }\end{array}$ \\
\hline
\end{tabular}

Table 3. Descriptive Statistics.

\begin{tabular}{|c|c|c|c|c|c|c|c|}
\hline Variable & Min. & Max. & Mean & Median & Skewness & Kurtosis & Obs. \\
\hline $\begin{array}{c}\text { Domestic } \\
\text { Saving Rate }\end{array}$ & -86.91 & 57.63 & 24.27 & 23.90 & -1.71 & 27.58 & 1080 \\
\hline $\begin{array}{c}\text { Domestic } \\
\text { Investment } \\
\text { Rate }\end{array}$ & 4.452 & 43.44 & 22.35 & 22.14 & 0.55 & 5.196 & 1080 \\
\hline
\end{tabular}

\section{METHODOLOGICAL APPROACH}

This section explains the methodological framework, which is the basis of the empirical analysis. In that vein, first, we present the theoretical content of the first- and secondgeneration unit root tests. Second, we specify the details of cointegration tests regarding whether there is a cointegrated relationship between saving and investment rates. Third, we examine the theoretical basis of the panel Granger causality test. Finally, the panel DOLS and panel FMOLS methods are explained for analyzing the existence of long-run coefficients among the relevant variables.

\subsection{First-Generation Panel Unit Root Tests}

The first-generation panel unit root approaches to test whether the series contain unit root or not are investigated by the testing procedures developed by Maddala and $\mathrm{Wu}$ (1999), Hadri (2000), Levin et al. (2002), and Im et al. (2003). The common point of these procedures is that the regression analysis follows the equation structure of Augmented Dickey-Fuller (ADF) tests (Dickey and Fuller, 1979), which is described in Equation (2):

$\Delta x_{i t}=\alpha_{i}+\beta_{i t}+\rho_{i} x_{i t-1}+\varepsilon_{i, t}$

where cit denotes the error term, which exhibits normal distribution with independent, zero mean, and constant variance. The null (H0) and alternative (Ha) hypotheses for unit root can be represented as follows:

$$
\begin{aligned}
& H_{0}: \rho_{i}=0\left(\text { for all } i^{\prime} s\right) \\
& H_{0}: \rho_{i}=\rho<0\left(\text { for all } i^{\prime} s\right)
\end{aligned}
$$

First, Maddala and $\mathrm{Wu}$ (1999), following the method of Fischer (1932), state that the probability values of the test statistics for the unit root in each cross-section unit should be considered. In this framework, the test statistics for the method developed by Maddala and Wu (1999) (hereafter MW) are measured as represented in Equation (3):

$$
M W=-2 \sum_{i=1}^{N} \operatorname{In}\left(\rho_{i}\right)
$$

Equation (3) reflects the test statistics of probability value for the ADF test statistics on behalf of each unit.

Second, Hadri's (2000) approach is based on the null hypothesis implying that the series are stationary. In that vein, it follows a similar background to the unit root test developed by Kwiatkowski et al. (1992). Within the validity of the assumption that the null hypothesis implies that the series are stationary, the new model can be described as in Equation (4):

$$
x_{i t}=r_{i t}+\beta_{i} t+\varepsilon_{i t}
$$

where the error term has a random walk, which is measured as in Equation (5):

$r_{i t}=r_{i t-1}+u_{i t}$

The disturbance term in Equation (5) is also called as white noise. In that sense, it is accepted as $E\left(u_{i t}\right)=0$ and $E\left(u_{i t}^{2}\right)=\sigma_{u_{i t}}^{2}>0$. The null hypothesis for Hadri's approach can be represented as follows:

$H_{0}: \sigma_{u}^{2}=0$ 
Third, Im et al. (2003) develop a unit root testing procedure using the approach done by Levin and Lin (1992), which allows for the heterogeneity of the values of $\rho$. In consideration of this framework, the alternative hypothesis is conducted as follows:

$$
H_{0}: \rho_{i}<0\left(p_{i}=0\right)
$$

$\mathrm{t}$ statistics reflect the average value and thereby are measured as in Equation (6):

$\bar{t}=\frac{1}{n} \sum_{1}^{N} t_{i}$

where $t$ denotes the individual ADF t-statistics for the unit root test.

Finally, Levin et al.'s (2002) approach is based on the alternative hypothesis. In other words, it is assumed that the autoregressive coefficient among units is homogeneous. Based on this, the difference between different units is tested with fixed effects.

\subsection{Second-Generation Panel Unit Root Test}

In terms of second-generation panel unit root tests, the stationary of the series is tested with the method developed by Pesaran (2007). The methodological background of this testing procedure refers that the series of xit is adjusted with both the individual average of xit- 1 and $\Delta x i t-1$. In that vein, we employ the cross-sectionally augmented Dickey-Fuller (CADF) test. In essence, the model, based upon this method, uses the testing approach of Im et al. (2003). Equation (7) represents the CADF test as follows:

$\Delta x_{i t}=\alpha_{i}+\rho_{i} x_{i t-1}+\varepsilon_{i t}$

where the disturbance term defines the common factor and thereby implies that $\varepsilon_{i, t}=\gamma_{i} \theta_{t}+u_{i t}$. The $u_{\text {it }}$ is the white noise error term.

Equation (8) describes the CADF model with no autocorrelation in $u_{i t}$ :

$\Delta x_{i t}=\alpha_{i}+\rho_{i} x_{i t-1}+c_{i} \bar{x}_{t-1}+d_{i} \Delta \bar{x}_{t-1}+v_{i t}$

Furthermore, the Pesaran statistics based on the CADF model can be produced using Equation (9):

$$
\operatorname{CIPS}(N, T)=\frac{1}{N} \sum_{i=1}^{N} t_{i}(N, T)
$$

\subsection{Panel Cointegration Tests}

Following the unit root test results, we examine the empirical strategy which is based on testing the cointegrating relationship among the series. In that vein, we use two different types of panel cointegration tests developed by Kao (1999) and Pedroni $(1999,2004)$. First, the cointegration test proposed by Pedroni $(1999,2004)$ controls the cross-sectional dependence. Thus, it investigates the presence of a cointegrating relationship among the series through seven kinds of tests. On the one hand, four of these tests use within estimators, i.e., panel- $v$, panel- $\rho$, non-parametric panel-t, and parametric panel-t. On the other hand, the rest of the three use between estimators, i.e., group- $\rho$ statistics, non-parametric group-t, parametric group-t. To apply the testing procedure developed by Pedroni $(1999,2004)$, the corresponding model is based on Equation (10):

$$
y_{i t}=\alpha_{i}+\beta_{i} t+\beta_{1 i t} x_{1 i t}+\beta_{2 i t} x_{2 i t}+\ldots+\beta_{k i t} x_{k i t}+\varepsilon_{i, t}
$$

where $\alpha_{i}$ represents the unit effects and $\beta_{i} t$ denotes the trend effects. The cointegration vector causes to differ from panel unit coefficients. All $\beta$ s are the parameters for the estimation of models. The null hypothesis states that the series are not cointegrating among each other. However, the alternative hypothesis denotes that the series have a cointegrating relationship.

The second method for testing the cointegrating relations among the series depends on the works of Kao (1999). It is based on the theoretical approach proposed by Engle and Granger (1987). The disturbance term is also harmonized with the DF- or ADF-type unit root tests (Baltagi and Kao, 2000; Asteriou and Hall, 2007). The DF-type testing procedures can be measured from the residuals of estimation values along with the use of the model representing in Equation (11) as follows:

$$
y_{i t}=x_{i t}^{\prime} \beta+s_{i t}^{\prime} \gamma+e_{i t}
$$

The null hypothesis in Kao's (1999) method reflects the case that there is no cointegrating relationship among the series. Furthermore, Kao (1999) proposes two different specification procedures. The pooled auxiliary regression is estimated in Equation (12) as follows:

$$
\epsilon_{i t}=\rho \epsilon_{i t-1}+v_{i t}
$$

Also, the extended version of pooled regression is estimated by the following model representing in Equation (13):

$$
\epsilon_{i t}=\rho \epsilon_{i t-1}+\sum_{j=1}^{\rho} \psi_{j} \Delta \epsilon_{i t-j}+v_{i t}
$$

All in all, the next sub-section will be based on the explanation of theoretical background of the panel Granger causality test proposed by Dumitrescu and Hurlin (2012).

\subsection{Panel Granger Causality Test}

The panel causality test developed by Dumitrescu and Hurlin (2012) can be considered as the distinguishing method in terms of providing effective estimates for each unit based on a highly sensitive analysis in the number of observations. In essence, it provides a great advantage over other causality tests due to the exclusion of the relationship between time and cross-sections. Equation (14) describes the panel causality test model in which the values of the stationary series are included as follows:

$$
y_{i t}=\alpha_{i}+\sum_{k=1}^{k} y_{i}^{(k)} y_{i t-k}+\sum_{k=1}^{k} \beta_{i}^{(k)} x_{i t-k}+e_{i t}
$$


The causality relationship between $\mathrm{x}$ and $\mathrm{y}$, representing in Equation (14), is grounded on the basis of the F-test and thereby is estimated using the null hypothesis, which indicates that there is no homogeneous Granger causality linkage in all units. Following the rejection of the null hypothesis based on statistical values obtained from the estimations, a two-way analysis is provided by reversing the causality relationship between the variables (Lopez and Weber, 2017). In this vein, the Dumitrescu-Hurlin panel Granger causality test is based on heterogeneous modeling. Within the framework of the given hypotheses, the null hypothesis points out the homogeneity of the model and the alternative hypothesis indicates the heterogeneity of the model. The series should be stationary for the effectiveness of test results. Therefore, the stationary of the series should be tested using panel unit root tests. Equation (15) represents the statistical basis of the values obtained by the average of Wald statistics to test the null hypothesis:

$W_{N, T}^{H n c}=\frac{1}{N}+\sum_{i=1}^{N} W_{i t}$

In Equation (15), $W_{i t}$ is the Wald statistics used to test Granger causality based on i unit. Two different test statistics are considered for the Wald estimates: (i) the asymptotic test statistic where $\mathrm{T}$ and $\mathrm{N}$ go to infinity and (ii) the semiasymptotic test statistic where $\mathrm{T}$ is constant. Furthermore, this testing procedure for detecting the causality between the variables has great importance in the literature since it provides statistically effective results in the analysis of models with fewer panels.

\subsection{DOLS and FMOLS Tests}

Another group of methods that the paper is used are Dynamic Ordinary Least Squares (DOLS) and Fully Modified Ordinary Least Squares (FMOLS) to estimate the long-run panel cointegration relationship among the series. The main goal of using these methods is that the OLS estimators could pose some theoretical problems. For instance, the dynamic effect between the variables cannot be estimated with the OLS method. Also, the use of the OLS method for estimating the models with small samples may result in providing an inefficient estimate and may also cause R-square to present biased results. Furthermore, the use of the OLS method having two or more explanatory variables using in the models make it difficult to interpret the correlation between the variables due to the emergence of multiple cointegrated linkages. Moreover, since the OLS method cannot solve the endogeneity problem, it may cause biased results for the coefficient estimates. Therefore, those kinds of problems lead to the emergence of new methods such as panel DOLS and panel FMOLS.

First, the DOLS method is developed by Stock and Watson (1993) to eliminate the statistical problems arising from the OLS method by considering the small sample and the dynamic structure of the series. This method particularly eliminates the endogeneity problem as a result of including the lagged variables of the independent variables to the model structure. Also, if there is a serial correlation problem in the model, it is solved with Generalized Least Squares (GLS) method. Equation (16) describes the model estimation based on the DOLS method:

$$
Y_{t}=\beta_{0}+\vec{\beta} X+\sum_{j=-q}^{\rho} \vec{d} j_{j} \Delta X_{t-j}+u_{t}
$$

where $Y_{t}$ is the dependent variable, $x$ is the vector of independent variables, $P$ is the cointegration vector, $P$ is the lag length, and $q$ is the next period value.

Second, besides the DOLS method, the other is called as FMOLS method developed by Phillips and Hansen (1990) to estimate the optimal values of models with cointegration. The main goal of using the FMOLS method is to get effective and unbiased parameter estimates by eliminating diagnostic problems such as autocorrelation and heteroskedasticity that arise due to the OLS method. However, the explanatory variables must be stationary in either I (1) or I (0) to use the FMOLS method, which is represented in Equation (17) as follows:

$Y_{t}=A X_{t}+u_{0 t}$

where $\mathrm{A}$ is the matrix with the size of $\mathrm{n} \times \mathrm{m}$. In addition, $X_{t}$ is the cointegration vector with the size of $\mathrm{m}=(\mathrm{m} 1+\mathrm{m} 2)$. Another advantage of using the FMOLS method within the framework of Pedroni's (2000) assumption is that the model results are sufficient to get robust values even in small sample estimations. As a result, the long-run relationship among the cointegrated series is measured by panel DOLS and panel FMOLS method, where the statistically robust prediction coefficients can be obtained. All in all, in the next section, we summarize the empirical results within the framework of those methods.

\section{EMPIRICAL RESULTS}

We investigate the degree of financial integration for selected 27 European countries from 1980 to 2019 using a dynamic panel data approach. In that vein, the statistical validity of the F-H puzzle is tested by the investigation of four different empirical steps. In the first step, we examine the stationary of the series using first- and second-generation panel unit root tests. In the second step, in consideration of those test results, we investigate the cointegration relationship among the series. If this is provided, the next step considers the examination of causality between the saving and investment rates. In the final step, we use dynamic methods for measuring the values and the direction of long-run coefficients.

\subsection{Panel Unit Root Analysis}

Tables 4 and 5 summarize panel unit root tests, covering first- and second generation. According to the tables, the panel unit root analyses for the saving and investment rates are given at their level and first-difference values, respectively. In each table, the values for the unit root tests consist of the models with trend and without a trend. Besides Hadri's (2000) unit root testing procedure, the null hypothesis of the others implies that there is at least one unit root in the series. The lag length in each analysis considers the Akaike Information Criterion (AIC). 
Table 4. Panel Unit Root Tests at Levels.

\begin{tabular}{|c|c|c|c|c|}
\hline \multirow{3}{*}{ Unit Root Tests } & \multicolumn{2}{|c|}{ Model without Trend } & \multicolumn{2}{|c|}{ Model with Trend } \\
\hline & \multicolumn{4}{|c|}{$s a v_{i t}$} \\
\hline & Test statistics & $p$-values & Test statistics & $p$-values \\
\hline MW & $90.20 * * *$ & 0.0015 & $89.89 * * *$ & 0.0016 \\
\hline Hadri & $54.60 * * *$ & 0.0000 & $35.38 * * *$ & 0.0000 \\
\hline IPS & $-2.723^{* * *}$ & 0.0032 & $-2.776^{* * * *}$ & 0.0028 \\
\hline LLC & $-3.464 * * *$ & 0.0003 & $-3.809 * * *$ & 0.0001 \\
\hline \multirow[t]{2}{*}{ CIPS } & -1.956 & 0.152 & -2.176 & 0.833 \\
\hline & \multicolumn{4}{|c|}{$i n v_{i t}$} \\
\hline MW & $125.13 * * *$ & 0.0000 & $103.46^{* * *}$ & 0.0001 \\
\hline Hadri & $43.09^{* * *}$ & 0.0000 & $30.99 * * *$ & 0.0000 \\
\hline IPS & $-5.559 * * *$ & 0.0000 & $-3.801 * * *$ & 0.0001 \\
\hline LLC & $-6.231 * * *$ & 0.0000 & $-4.729 * * *$ & 0.0000 \\
\hline CIPS & $-2.245^{* * *}$ & 0.004 & -2.482 & 0.202 \\
\hline
\end{tabular}

Notes: savit and invit for saving rate (\% of GDP) and investment rate (\% of GDP). Unit root hypothesis is rejected at $* * * 1 \%, * * 5 \%, * 10 \%$ levels. For Hadri's test (2000), the unit root hypothesis is the alternative hypothesis. MW, IPS, LLC, and CIPS for Maddala and Wu (1999), Levin et al. (2002), Im et al. (2003), and Pesaran (2007) tests results. The lag length is determined by way of the Akaike Information Criterion (AIC).

Table 4 shows the unit root test of the series at levels. The test statistics and their corresponding $\mathrm{p}$-values indicate that the null hypothesis of the presence of common unit root is rejected for all the first-generation methods, instead of the Hadri (2000), at the levels. Also, the CIPS statistics show that the series are not stationary at the levels. Therefore, those findings lead us to measure the panel unit root tests at the first differences of series.

Table 5 summarizes the unit root test results of the series at their first differences. According to the empirical findings, all the series are stationary at the first differences at the $1 \%$ significance level. In other words, even in the control of homogeneous and heterogeneous cross-sections with the crosssectional dependence, the models with trend and without trend show that the null hypothesis is rejected. Also, Hadri's test (2000), where the unit root hypothesis is the alternative, implies that the series are stationary. Therefore, those results lead us to analyze the cointegrating relationship among the series, representing in the next sub-section 5.2.

Table 5. Panel Unit Root Tests at First Differences.

\begin{tabular}{|c|c|c|c|c|}
\hline \multirow{2}{*}{ Unit Root Tests } & \multicolumn{3}{|c|}{ Model without Trend } & \multicolumn{2}{c|}{ Model with Trend } \\
\cline { 2 - 5 } & \multicolumn{4}{|c|}{ dsav $_{\text {it }}$} \\
\cline { 2 - 5 } & $\begin{array}{c}\text { Test statis- } \\
\text { tics }\end{array}$ & $\boldsymbol{p}$-values & Test statistics & $\boldsymbol{p}$-values \\
\hline MW & $552.76^{* * *}$ & 0.0000 & $444.98^{* * *}$ & 0.0000 \\
\hline Hadri & -1.884 & 0.9702 & -1.149 & 0.8746 \\
\hline
\end{tabular}

\begin{tabular}{|c|c|c|c|c|}
\hline \multirow{3}{*}{ Unit Root Tests } & \multicolumn{2}{|c|}{ Model without Trend } & \multicolumn{2}{|c|}{ Model with Trend } \\
\hline & \multicolumn{4}{|c|}{ dsavit $_{i t}$} \\
\hline & $\begin{array}{l}\text { Test statis- } \\
\text { tics }\end{array}$ & $p$-values & Test statistics & $p$-values \\
\hline MW & $552.76^{* * *} *$ & 0.0000 & $444.98 * * *$ & 0.0000 \\
\hline Hadri & -1.884 & 0.9702 & -1.149 & 0.8746 \\
\hline IPS & $-24.34 * * *$ & 0.0000 & $-22.10 * * *$ & 0.0000 \\
\hline LLC & $-24.32 * * *$ & 0.0000 & $-20.56 * * *$ & 0.0000 \\
\hline \multirow[t]{2}{*}{ CIPS } & $-4.461 * * *$ & 0.000 & $-4.573 * * *$ & 0.000 \\
\hline & \multicolumn{4}{|c|}{$\operatorname{dinv}_{i t}$} \\
\hline MW & $395.07 * * *$ & 0.0000 & $296.42 * * *$ & 0.0000 \\
\hline Hadri & -0.649 & 0.7418 & 1.108 & 0.1338 \\
\hline IPS & $-20.377 * * *$ & 0.0000 & $-17.986^{* * * *}$ & 0.0000 \\
\hline LLC & $-20.169 * * *$ & 0.0000 & $-17.037 * * *$ & 0.0000 \\
\hline CIPS & $-4.296^{* * *}$ & 0.000 & $-4.325 * * *$ & 0.000 \\
\hline
\end{tabular}

Notes: dsavit and dinvit for the first differences of saving rate (\% of GDP and investment rate (\% of GDP). Unit root hypothesis is rejected at $* * * 1 \%$, ** 5\%, * $10 \%$ levels. For Hadri's test (2000), the unit root hypothesis is the alternative hypothesis. MW, IPS, LLC, and CIPS for Maddala and Wu (1999), Levin et al. (2002), Im et al. (2003), and Pesaran (2007) tests results. The lag length is determined by way of AIC.

\subsection{Panel Cointegration Analysis}

One of the primary reasons for performing the cointegration test is to get rid of the spurious regression in the modeling process. In consideration of unit root test results, the existence of long-run linkages between the series is considered to be statistically more reliable. In this subsection, the long-run cointegrating relations for the variables of saving rate and investment rate are tested with two different models using the tests developed by Kao (1999) and Pedroni (1999, 2004). The lag length is selected through the consideration of AIC. The cointegration test results are summarized in Table 6 for a given model grounded on the F-H puzzle.

In particular, the results over the period 1980-2019 show that the series are cointegrated. In Table 6 , the cointegration test results are summarized for this model, where the investment rate is considered as a dependent variable and the saving rate is considered as an independent variable. The test statistics and the p-values emphasize that the null hypothesis, implying that there is no cointegrated linkage among the series, is rejected at the $1 \%$ significance level both for the model with constant and the model with constant and trend. All the cointegration tests are derived using the EViews software (version 10.0). For the robustness of those two tests, we also employ the Johansen Fisher panel cointegration test. This is done for testing the statistical reliability of the cointegrated relationship among the series. Related to the test statistics, it is clear to assume that the model shows that there is a longrun relationship between the variables. In that sense, the next subsection points out the causality relationship between the variables to determine whether there is a two-way linkage or not. 
Table 6. Panel Cointegration Tests.

\begin{tabular}{|c|c|c|c|c|}
\hline & \multicolumn{4}{|c|}{$\mathrm{INV}_{\mathrm{it}}=\alpha_{\mathrm{it}}+\beta \mathrm{SAV}_{\mathrm{it}}+\varepsilon_{\mathrm{it}}$} \\
\hline & \multicolumn{4}{|c|}{ Pedroni Residual Cointegration Test } \\
\hline & \multicolumn{4}{|c|}{ (Within-dimension) } \\
\hline & Statistic & $p$-values & $\begin{array}{c}\text { Weighted Statis- } \\
\text { tic }\end{array}$ & $p$-values \\
\hline Panel v-statistic & $1.8916^{* *}$ & 0.0293 & $1.9288 * *$ & 0.0269 \\
\hline Panel rho-statistic & $-1.6733 * *$ & 0.0471 & $-1.6803 * *$ & 0.0464 \\
\hline Panel PP-statistic & $-2.2494 * *$ & 0.0122 & $-2.3401 * * *$ & 0.0096 \\
\hline \multirow[t]{3}{*}{$\begin{array}{c}\text { Panel ADF- } \\
\text { statistic }\end{array}$} & $-2.3609 * * *$ & 0.0091 & $-3.5761 * * *$ & 0.0002 \\
\hline & \multicolumn{4}{|c|}{ (Between-dimension) } \\
\hline & Statistic & $p$-values & & \\
\hline Group rho-statistic & -0.2219 & 0.4122 & & \\
\hline Group PP-statistic & $-1.5344 *$ & 0.0625 & & \\
\hline \multirow[t]{3}{*}{$\begin{array}{l}\text { Group ADF- } \\
\text { statistic }\end{array}$} & $-4.5765 * * *$ & 0.0000 & & \\
\hline & \multicolumn{4}{|c|}{ Kao Residual Cointegration Test } \\
\hline & $t$-statistic & $p$-values & & \\
\hline $\mathrm{ADF}$ & $-4.2945 * * *$ & 0.0000 & & \\
\hline Residual variance & 3.6464 & & & \\
\hline \multirow[t]{2}{*}{ HAC variance } & 3.6725 & & & \\
\hline & \multicolumn{4}{|c|}{ Johansen Fisher Panel Cointegration Test } \\
\hline $\begin{array}{c}\text { Hypothesized no. } \\
\text { of } \mathrm{CE}(\mathrm{s})\end{array}$ & $\begin{array}{l}\text { Fisher stat. } \\
\text { (from trace } \\
\text { test) }\end{array}$ & $p$-values & $\begin{array}{c}\text { Fisher stat. } \\
\text { (from max-eigen } \\
\text { test) }\end{array}$ & $p$-values \\
\hline None & $112.6^{* * *}$ & 0.0000 & $111.5^{* * *}$ & 0.0000 \\
\hline At most 1 & 46.88 & 0.7430 & 46.88 & 0.7430 \\
\hline
\end{tabular}

Notes: savit and invit for saving rate (\% of GDP) and investment rate (\% of GDP). The null hypothesis is rejected at $* * * 1 \%, * * 5 \%, * 10 \%$ significance levels. The lag length is selected through the use of AIC.

\subsection{Panel Granger Causality Analysis}

The third stage covers that the causality relationship between the saving and investment rates is investigated to examine the existence of a long-run linkage among the series. The main purpose of this procedure is to determine the direction of the relationships that exist between the variables. In that vein, the panel causality method developed by Dumitrescu and Hurlin (2012) is used to test the relevant process. The null hypothesis of the test method that we discuss is based on "the $\mathrm{X}$ variable is not the cause of the $\mathrm{Y}$ variable in all crosssection units". Table 7 shows the statistical values of the causality relationship between saving and investment rates.
In particular, the Dumitrescu-Hurlin panel Granger causality procedure considers the determination of the lag length, which has great importance related to the statistical framework. The lag length should be determined to obtain a reliable output about the statistical validity of the relevant findings and the direction of causality between the variables. Therefore, the causality analysis is tested considering AIC for the lag length.

The test statistics in Table $\mathbf{7}$ indicate that the null hypothesis, which implies that there is no causality linkage between the series, is rejected for both directions. In other words, based on the current probability values, the Dumitrescu-Hurlin panel causality test results show that there is a bidirectional relationship at the $1 \%$ significance level between the variables over the 1980-2019 period across the European countries. In that vein, the saving rate does Granger-cause investment rate for at least one panel and investment rate does Granger-cause saving rate for at least one panel. Figure 2 depicts the bidirectional relationship among the series.

Table 7. Dumitrescu-Hurlin Panel Causality Test.

\begin{tabular}{|c|c|c|c|}
\hline $\begin{array}{c}\mathrm{H}_{0} \text { : The X variable does not cause Y } \\
\text { variable }\end{array}$ & Lag length & $\begin{array}{c}W_{N, T}^{H n c} \\
\text { statistics }\end{array}$ & $p$-values \\
\hline $\operatorname{sav}_{i t} \neq>$ inv $_{i t}$ & 11 & $25.1037 * * *$ & 0.0000 \\
\hline inv $_{i t} \neq>\operatorname{sav}_{i t}$ & 11 & $19.2564 * * *$ & 0.0000 \\
\hline
\end{tabular}

Notes: savit and invit for saving rate (\% of GDP) and investment rate (\% of GDP). The null hypothesis is rejected at $* * * 1 \%, * * 5 \%, * 10 \%$ significance levels. The lag length is selected through the use of AIC.

As can be understood from Fig. (2), the bidirectional causality relationship between the variables causes each variable to affect one another. However, the relevant causality analysis lacks the infrastructure to evaluate the existence or magnitude of positive and negative linkages between the variables. For this reason, in the presence of a long-run relationship between the variables, which is the further step in the empirical section of the study, the coefficients of the positive or negative directions and their magnitudes are estimated in the next subsection with DOLS and FMOLS methods.

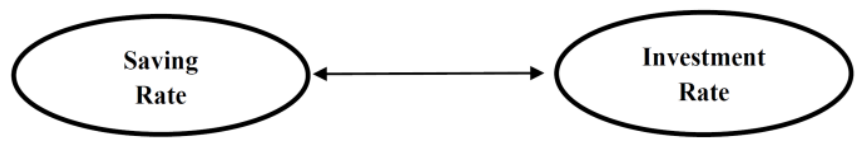

Fig. (2). The bidirectional causality linkage.

Source: The authors' representation.

\subsection{DOLS and FMOLS Estimates}

The last technical step of the study focuses on the estimation of the long-term coefficients of the variables included in the models and the direction of the relationship among the two, which are analyzed through the panel DOLS and FMOLS methods. However, three different conditions need to be met to get statistically reliable results in case of these procedures. First, the stationary of the series should be provided at the first differences in I (1). Therefore, the relevant part for the 
analysis, which takes into account of different diagnostic issues, tests the stationary conditions of each series by way of five different panel unit root procedures within the framework of both first- and second-generation methods. The results of stationary for the series show that they have no unit root in I (1). Secondly, the cointegrating linkage among the stationary series should be investigated with several models. In this study, three different panel cointegration tests were used to reveal the fact that each test statistic has been examined through the inclusion of both the constant term and the term with constant and trend. All estimates show that the cointegrated relationship among the series are available. Third, the causality relationship between the variables was investigated to test whether there was a long-term correlation among the series. The results for the binary combinations of variables used in the models, which are established simultaneously, showed that there is a bidirectional causality relationship between the variables. Thus, the statistical requirements for the use of panel DOLS and FMOLS methods in all three estimation stages of the analysis were met. In that vein, the last stage of the study deals with the estimation of longterm cointegration along with testing the directions of variables in consideration of taking their weighted averages for two models where each variable is treated as a dependent variable, respectively. Table 8 represents four different regression results based on the use of panel DOLS and FMOLS methods for Model 1 and Model 2. The lag lengths are determined through the Akaike Information Criterion (AIC). Also, the number of lags and leads for the DOLS method is valued as -1 and 1 , respectively.

Table 8. Panel DOLS and Panel FMOLS Methods.

\begin{tabular}{|c|c|c|c|c|}
\hline \multicolumn{5}{|c|}{ Model 1: $\operatorname{sav}_{i t}=\alpha_{i t}+\beta_{1} i n v_{i t}+u_{i t}$} \\
\hline & \multicolumn{2}{|c|}{ DOLS } & \multicolumn{2}{|c|}{ FMOLS } \\
\hline & $\beta_{1}$ coefficient & $p$-value & $\beta_{1}$ coefficient & $p$-value \\
\hline Pooled & $0.6324 * * *$ & 0.0000 & $0.6394 * * *$ & 0.0000 \\
\hline $\begin{array}{c}\text { Pooled } \\
\text { (weighted) }\end{array}$ & $0.4103 * * *$ & 0.0000 & $0.4504 * * *$ & 0.0000 \\
\hline Grouped & $0.1849 * * *$ & 0.0019 & $0.2155^{* * *}$ & 0.0000 \\
\hline \multicolumn{5}{|c|}{ Model 2: $i n v_{i t}=\alpha_{i t}+\beta_{1} s a v_{i t}+u_{i t}$} \\
\hline & \multicolumn{2}{|c|}{ DOLS } & \multicolumn{2}{|c|}{ FMOLS } \\
\hline & $\beta_{l}$ coefficient & $p$-value & $\beta_{1}$ coefficient & $p$-value \\
\hline Pooled & $0.3092 * * *$ & 0.0000 & $0.2763 * * *$ & 0.0000 \\
\hline $\begin{array}{c}\text { Pooled } \\
\text { (weighted) }\end{array}$ & $0.3281 * * *$ & 0.0000 & $0.2908 * * *$ & 0.0000 \\
\hline Grouped & $0.3199 * * *$ & 0.0000 & $0.2559 * * *$ & 0.0000 \\
\hline
\end{tabular}

Notes: savit and invit for saving rate (\% of GDP) and investment rate (\% of GDP). The null hypothesis is rejected at $* * * 1 \%, * * 5 \%, * 10 \%$ significance levels. The trend specification for the two methods is selected as a linear trend. The additional trends are none. Pooled, pooled (weighted), and grouped show the panel methods. The lag and lead methods in the DOLS tests are selected as Akaike.
First, in Model 1, $\beta 1$ coefficient and the corresponding probability values for different panel methods in the framework of the panel DOLS and FMOLS tests are given in the regression equation in which the saving rate is the dependent variable, and the investment rate is the explanatory variable. Since they are at levels in all models, the estimation coefficients cannot represent the elasticities of the variables. Rather, they have to be interpreted from the way of unit changes. Each panel method (pooled, pooled (weighted), and grouped) result in Model 1 for the panel DOLS test shows that the long-term coefficient of investment rate is 0.6326 , 0.4103 , and 0.1849 , respectively. According to the p-values, they are all statistically significant at the $1 \%$ level. The estimated coefficients indicate that a one-unit increase in investment leads to $0.6326,0.4103$, and 0.1849 unit increases in saving for each respective method. Likewise, Model 1 also represents the estimations for coefficients of investment rate produced by the panel FMOLS method. Each panel method (pooled, pooled (weighted), and grouped) result in Model 1 for the panel FMOLS test shows that the long-term coefficient of investment rate is $0.6394,0.4504$, and 0.2155 , respectively. According to p-values, they are all statistically significant at the $1 \%$ level. The estimated coefficients show that a one-unit increase in investment leads to 0.6394, 0.4504 , and 0.2155 unit increases in saving for each respective method.

Second, in Model 2, $\beta 1$ coefficient and the corresponding probability values for different panel methods in the framework of the panel DOLS and FMOLS tests are given in the regression equation in which the investment rate is the dependent variable, and the saving rate is explanatory variables. Each panel method (pooled, pooled (weighted), and grouped) result in Model 2 for the panel DOLS test shows that the long-term coefficient of saving rate is 0.3092 , 0.3281 , and 0.3199 , respectively. According to the p-values, they are all statistically significant at the $1 \%$ level. The estimated coefficients indicate that one unit increase in saving leads to $0.3092,0.3281$, and 0.3199 unit increases in investment for each respective method. Likewise, Model 2 also represents the estimations for coefficients of saving rate produced by the panel FMOLS method. Each panel method (pooled, pooled (weighted), and grouped) result in Model 2 for the panel FMOLS test shows that the long-term coefficient of saving rate is $0.2763,0.2908$, and 0.2559 , respectively. According to p-values, they are all statistically significant at the $1 \%$ level. The estimated coefficients show that a one-unit increase in saving leads to $0.2763,0.2908$, and 0.2559 unit increases in investment for each respective method.

\section{CONCLUDING REMARKS}

This study investigated the relevance of financial integration in consideration of the F-H puzzle across the selected 27 European countries over the 1980-2019 period. In particular, the distinguishing feature of this study is to consider the ongoing debate from the view of the dynamic panel data approach, covering the panel unit-root tests, cointegration analysis, panel Granger causality tests, and the DOLS and FMOLS methods. Even though the discussions on the F-H puzzle is not a new issue, the current literature has a bulk of findings which are all inconclusive and controversial. There- 
fore, this mixed conclusion on one of the most challenging puzzles in international economics leads many researchers to investigate its different conditions across different countries. A various number of studies show that some of the major reasons along with those mixed outputs can be classified as follows: (i) sample selection problem, (ii) size distortion, (iii) simultaneity bias, (iv) misspecification error, (v) interdependency of financial shocks, (vi) omitted variable bias, and (vii) non-linearity problem.

To test the relevance of the F-H puzzle for the selected 27 European countries, the current study used two core variables, i.e., saving rate and investment rate, which are obtained from the World Development Indicators database. In that vein, the relationship between saving and investment rates has been investigated through four different panel data approaches. In the first step, the stationary levels of the series were examined using five different methods within the framework of the first- and second-generation panel unit-root tests. It has been observed that the series have an integrated of order one, i.e., I (1). In other words, they are stationary at their first differences. In the second step, the cointegration relationship among the series was analyzed by way of three different methods. As a result of using those methods for an investigation of the cointegrating relationship among the series, it was seen that the cointegrating linkage is prevailing for all established models. Therefore, the causality relationship between the variables, which is considered as the third step, was tested through the panel Granger causality analysis developed by Dumitrescu and Hurlin (2012). The empirical findings indicated that each variable is both a cause and a result of each other. In other words, the causality relationship between the variables is bidirectional. In the last step, the panel DOLS and FMOLS methods were used to get rid of the diagnostic issues such as autocorrelation, heteroskedasticity, and/or endogeneity that may arise in the analysis of models. The main purpose to use panel DOLS and FMOLS methods is to get statistically reliable and unbiased long-term coefficients. In that sense, the long-term coefficients based on two models where each variable is considered as a dependent variable showed that the relationship between the variables was statistically significant at the $1 \%$ level. Unlike mainstream approaches, it has been observed that there is a positive correlation between the saving rate and investment rate. In other words, these different estimations indicated that there is a high degree of financial integration across the selected 27 European countries over the 1980-2019 period. So that, the empirical findings showed that those countries have strong financial integration in testing the F-H puzzle.

\section{CONFLICT OF INTEREST STATEMENT}

The authors declare that they have no conflict of interest.

\section{REFERENCES}

Alexakis, P. and Apergis, N. (1994). The Feldstein-Horioka puzzle and exchange rate regimes: Evidence from cointegration tests. Journal of Policy Modeling, 16(5), 459-472.

Asteriou, D. and Hall, S. G. (2007). Applied econometrics: A modern approach using Eviews and Microfit. New York: Palgrave Macmillan.

Baltagi, B. H. and Kao, C. (2000). Nonstationary panels, cointegration in panels and dynamic panels: A survey. Center for Policy Research, Working Paper No. 16, March.
Bangake, C. and Eggoh, J. C. (2011). The Feldstein-Horioka puzzle in African countries: A panel cointegration analysis. Economic Modelling, 28(3), 939-947.

Barros, C. P. and Gil-Alana, L. A. (2015). Investment and saving in Angola and the Feldstein-Horioka puzzle. Applied Economics, 47(44), 4793-4800.

Baxter, M. and Crucini, M. J. (1993). Explaining saving-investment correlations. American Economic Review, 83(3), 416-436.

Bayoumi, T., Sarno, L. and Taylor, M. P. (1999). European capital flows and regional risk. The Manchester School, 67(1), 21-38.

Beine, M., Cosma, A. and Vermeulen, R. (2010). The dark side of global integration: Increasing tail dependence. Journal of Banking and Finance, 34(1), 184-192.

Beitone, A., Gilles, P. and Parodi, M. (2006). Histoire des faits économiques et sociaux de 1945 à nos jours, Dalloz.

Bibi, N. and Jalil, A. (2016). Revisiting Feldstein-Horioka puzzle: Econometric evidences from common coefficient mean group model. Pakistan Economic and Social Review, 54(2), 233-254.

Cadoret, I. (2001). The saving investment relation: A panel data approach. Applied Economics Letters, 8(8), 517-520.

Caporale, G. M., Panopoulou, E. and Pittis, N. (2005). The FeldsteinHorioka puzzle revisited: A Monte Carlo study. Journal of International Money and Finance, 24(7), 1143-1149.

Cardia, E. (1992). Crowding out in open economies: Results from a simulation study. The Canadian Journal of Economics, 25(3), 708-728.

Chortareas, G. E., Kapetanios, G. and Uctum, M. (2004). An investigation of current account solvency in Latin America using non linear nonstationarity tests. Studies in Nonlinear Dynamics and Econometrics, 8(1), 1-19.

Coakley, J. and Kulasi, F. (1997). Cointegration of long span saving and investment. Economics Letters, 54(1), 1-6.

Coakley, J., Kulasi, F. and Smith, R. (1998). The Feldstein-Horioka puzzle and capital mobility: A review. International Journal of Finance and Economics, 3(2), 169-188.

De Vita, G. and Abbott, A. (2002). Are saving and investment cointegrated? An ARDL bounds testing approach. Economics Letters, 77(2), 293-299.

De Wet, A. and Van Eyden, R. (2005). Capital mobility in Sub-Saharan Africa: A panel data approach. South African Journal of Economics, 73(1), 22-35.

Devereux, M. P. (1996). Investment, saving, and taxation in an open economy. Oxford Review of Economic Policy, 12(2), 90-108.

Dickey, D. A. and Fuller, W. A. (1979). Distribution of the estimators for autoregressive time series with a unit root. Journal of the American Statistical Association, 74(366), 427-431.

Dumitrescu, E. I. and Hurlin, C. (2012). Testing for Granger noncausality in heterogeneous panels. Economic Modelling, 29(4), 1450-1460.

Edwards, S. (2004). Thirty years of current account imbalances, current account reversals and sudden stops. NBER Working Paper No. 10276, National Bureau of Economic Research.

Engle, R. F. and Granger, C. W. J. (1987). Cointegration and error correction: Representation, estimation, and testing. Econometrica, 55(2), 251-276.

Feldstein, M. (1983). Domestic saving and international capital movements in the long run and the short run. European Economic Review, 21(1-2), 129-151.

Feldstein, M. and Bacchetta, P. (1991). National savings and international investment. in D. Dernheim and J. Shoven (eds.), National saving and economic performance, 201-226, Chicago: University of Chicago Press.

Feldstein, M. and Horioka, C. (1980). Domestic saving and international capital flows. The Economic Journal, 90(358), 314-329.

Fischer, R. A. (1932). Statistical methods for research workers. Edinburgh: Oliver and Boyd.

Ghosh, A. R. (1995). International capital mobility amongst the major industrialised countries: Too little or too much? The Economic Journal, 105(428), 107-128.

Guillaumin, C. (2009). Financial integration in East Asia: Evidence from panel unit root and panel cointegration tests. Journal of Asian Economics, 20(3), 314-326.

Gunji, H. (2003). The Feldstein-Horioka puzzle and law. Economics Bulletin, 11(1), 1-12.

Hadri, K. (2000). Testing for stationary in heterogeneous panel data. Econometrics Journal, 3(2), 148-161. 
Hamada, K. and Iwata, K. (1989). On the international capital ownership pattern at the turn of the twenty-first century. European Economic Review, 33(5), 1055-1079.

Harberger, A. C. (1980). Vignettes on the world capital market. The American Economic Review, 70(2), 331-337.

Hassan, I. B., Azali, M. and Lee, C. (2014). Feldstein-Horioka puzzle and international capital mobility in high income countries: A pool mean group approach. Inzinerine Ekonomika-Engineering Economics, 25(5), 480-486.

Ho, T. W. (2002). The Feldstein-Horioka puzzle revisited. Journal of International Money and Finance, 21(4), 555-564.

Im, K., Pesaran, M. and Shin, Y. (2003). Testing for unit roots in heterogeneous panels. Journal of Econometrics, 115(1), 53-74.

Isaksson, A. (2001). Financial liberalisation, foreign aid, and capital mobility: Evidence from 90 developing countries. Journal of International Financial Markets, Institutions and Money, 11(3-4), 309-338.

Jansen, W. J. (1996). Estimating saving-investment correlations: Evidence for OECD countries based on an error correction model. Journal of International Money and Finance, 15(5), 749-781.

Jansen, W. J. (1998). Interpreting saving-investment correlations. Open Economies Review, 9(3), 207-219.

Kao, C. (1999). Spurious regression and residual-based tests for cointegration in panel data. Journal of Econometrics, 90(1), 1-44.

Kasuga, H. (2004). Saving-investment correlations in developing countries. Economics Letters, 83(3), 371-376.

Katsimi, M. and Zoega, G. (2016). European integration and the FeldsteinHorioka puzzle. Oxford Bulletin of Economics and Statistics, 78(6), 834-852.

Kwiatkowski, D., Phillips, P. C. B., Schmidt, P. and Shin, Y. (1992). Testing the null hypothesis of stationary against the alternative of a unit root: How sure are we that economic time series have a unit root? Journal of Econometrics, 54(1-3), 159-178.

Levin, A. and Lin, C. F. (1992). Unit root tests in panel data: Asymptotic and finite-sample properties. Discussion Paper No. 56, Department of Economics, University of California at San Diego.

Levin, A., Lin, C. F. and Chu, J. (2002). Unit root tests in panel data: Asymptotic and finite-sample properties. Journal of Econometrics, 108(1), 1-24.

Lopez, L. and Weber, S. (2017). Testing for Granger causality in panel data. University of Neuchatel Institute of Economic Research, Workin Paper No. 17-03.

Ma, W. and Li, H. (2016). Time-varying saving-investment relationship and the Feldstein-Horioka puzzle. Economic Modelling, 53, 166-178.

Maddala, G. S. and Wu, S. (1999). A comparative study of unit root tests and a new simple test. Oxford Bulletin of Economics and Statistics, 61(S1), 631-652.

Mosikari, T. J., Tsoku, J. T. and Xaba, D. L. (2017). Testing the validity of Feldstein-Horioka puzzle in BRICS countries. International Journal of Economics and Management Engineering, 11(4), 1009-1013.

Murphy, R. G. (1984). Capital mobility and the relationship between saving and investment rates in OECD countries. Journal of International Money and Finance, 3(3), 327-342.

Narayan, P. K. (2005a). The saving and investment nexus for China: Evidence from cointegration tests. Applied Economics, 37(17), 19791990.

Narayan, P. K. (2005b). The relationship between saving and investment for Japan. Japan and the World Economy, 17(3), 293-309.
Niehans, J. (1992). The international allocation of savings with quadratic transaction (or risk) costs. Journal of International Money and Finance, 11(3), 222-234

Obstfeld, M. (1986). Capital mobility in the world economy: Theory and measurement. Carnegie-Rochester Conference Series on Public Policy, 24, 55-103.

Obstfeld, M. and Rogoff, K. (2000). The six major puzzles in international macroeconomics: Is there a common cause? NBER Working Paper Series No. 7777, National Bureau of Economic Research.

Payne, J. E. and Kumazawa, R. (2006). Capital mobility and the FeldsteinHorioka puzzle: Re-examination of less developed countries. The Manchester School, 74(5), 610-616.

Pedroni, P. (1999). Critical values for cointegration tests in heterogeneous panels with multiple regressors. Oxford Bulletin of Economics and Statistics, 61(S1), 653-670.

Pedroni, P. (2000). Fully modified OLS for heterogeneous cointegrated panels. Advances in Econometrics, 15, 93-132.

Pedroni, P. (2004). Panel cointegration: Asymptotic and finite sample properties of pooled time series tests with an application to the PPP hypothesis. Econometric Theory, 20(3), 597-625.

Pesaran, H. M. (2007). A simple panel unit root test in the presence of crosssection dependence. Journal of Applied Econometrics, 22(2), 265312.

Phillips, P. C. and Hansen, B. E. (1990). Statistical inference in instrumental variables regression with I (1) processes. Review of Economic Studies, 57(1), 99-125.

Sachs, J. (1981). The current account and macroeconomic adjustment in the 1970s. Brookings Papers on Economic Activity, 12(1), 201-282.

Sarno, L. and Taylor, M. P. (1998). Exchange controls, international capital flows and saving-investment correlations in the UK: An empirical investigation. Review of World Economics, 134(1), 69-98.

Schmidt, J. (2016). Solving the Feldstein-Horioka puzzle. Paper Prepared for the 20th FMM Conference, Berlin, 20-22 October 2016, 'Towards Pluralism in Macroeconomics'.

Shibata, A. and Shintani, M. (1998). Capital mobility in the world economy: An alternative test. Journal of International Money and Finance, 17(5), 741-756.

Sinn, S. (1992). Saving-investment correlations and capital mobility: On the evidence from annual data. The Economic Journal, 102(414), 11621170 .

Stock, J. H. and Watson, M. W. (1993). A simple estimator of cointegrating vectors in higher order integrated systems. Econometrica, 61(4), 783-820.

Summers, L. H. (1988). Tax policy and international competitiveness. in J. Frenkel (ed.), International aspects of fiscal policies, 349-386, Chicago: University of Chicago Press.

Taslim, M. A. (1995). Saving investment correlation and capital mobility. UNE Working Papers in Economics, No. 18.

Tesar, L. L. (1991). Saving, investment and international capital flows. Journal of International Economics, 31(1-2), 55-78.

Vamvakidis, A. and Wacziarg, R. (1998). Developing countries and the Feldstein-Horioka puzzle. IMF Working Paper, No. 98/2.

Watson, M. (2001). International capital mobility in an era of globalisation: Adding a political dimension to the 'Feldstein-Horioka Puzzle'. Politics, 21(2), 81-92.

Wong, D. Y. (1990). What do saving-investment relationships tell us about capital mobility? Journal of International Money and Finance, 9(1), 60-74. 